\title{
PENGARUH LAYANAN INFORMASI BIMBINGAN KONSELING BERBANTUAN MEDIA AUDIO VISUAL TERHADAP EMPATI SISWA
}

\author{
Rita Kumalasari $^{1}$, Bambang Susanto ${ }^{2}$ \\ ${ }^{1}$ FKIP, Universitas Veteran Bangun Nusantara, Sukoharjo \\ rita.kumalasari17@yahoo.com \\ ${ }^{2}$ FKIP, Universitas Veteran Bangun Nusantara, Sukoharjo \\ bambang_susanto43@yahoo.com
}

\begin{abstract}
Penelitian ini dilatarbelakangi dari hasil observasi kurang berkembangnya empati siswa TK terhadap teman sebaya. Tujuan penelitian ini untuk mengetahui effektifitas layanan informasi bimbingan dan konseling berbantuan media audio visual terhadap empati siswa.

Penelitian ini mengunakan metode pada penelitian ini kuantitatif, dengan rancangan quasi-eksperimental, rancangan kelompok kontrol (Pra-tes dan Post- tes) (Nonequivalend (Pre-tes dan Post-tes) control-group design) dalam rancangan ini kelompok eksperimen (A) dan kelompok kontrol (B) diseleksi tanpa prosedur penempatan acak (without random assigment). Pada dua kelompok tersebut, sama-sama dilakukan pre-test dan pos-tes. Hanya kelompok eksperimen (A) saja yang diberikan treatment.

Hasil penelitian ini terbukti effektif terhadap empati siswa. Empati siswa mengalami kenaikan sebesar $28.9 \%$ dari sebelumnya $45.08 \%$ meningkat menjadi 73.98\%. hasil t-test untuk post-tes kelompok eksperimen dengan kelompok kontrol diketahui nilai t hitung 14.743, menunjukan bahwa nilai post -test pada kelompok eksperimen sebesar $0,000<0,05$ maka Ho ditolak, artinya ada beda rerata antara nilai post-tes kelompok eksperimen dengan kelompok kontrol. Hal ini dapat diartikan bahwa layanan informasi bimbingan konseling berbantuan media audio visual effektif terhadap empati siswa.
\end{abstract}

Kata kunci : Effektifitas, Audio Visual, Empati

\section{THE INFLUENCE OF INFORMATION SERVICE IN GUIDANCE COUNSELING BY AUDIO VISUAL MEDIA FOR STUDENTS' EMPATHY}

\begin{abstract}
This study is motivated from the result of observation that has under development empathy of kindergarten's students towards peers. The objective of this study is to find out the effectivity of information service in guidance and counseling by audio-visual media for studets' empathy.

This study used quantitative research with quasi-experimental design, control group design (pre-test and post-test) (Nonequivalend (Pre-test and post- test) control-group design) in this design the experimental group (A ) and the control group (B) is selected without random placement procedure (without random assigment. In these two groups, both performed a pre-test and post-test. Only the experimental group (A) are given
\end{abstract}


treatment.

The results of research effective of audio-visual media counseling techniques effective and practical to increase the empathy of students are rational design, key concepts, understanding, purpose, content models, the role and qualifications tutor (counselor) is expected, procedures or steps in the implementation of the audio-visual, evaluation, follow-up, support system. This research is proven effective in improving student behavior. Empathy behavior of students increases $28.9 \%$ from the previous $45.08 \%$ increase to $73.98 \%$. This increase occurred in all aspects of empathy

Keywords: Effective, Audio visual, Empathy

\section{PENDAHULUAN}

\begin{tabular}{lrr}
\multicolumn{1}{c}{ Empati pada anak } & usia dini \\
merupakan & bagian & tahap \\
perkembangan & sosial. & Hoffman
\end{tabular}
(2001 : 487- 488) menyatakan bahwa perkembangan empati sejak usia dini adalah pondasi awal perilaku prososial termasuk perilaku keadilan dan pertimbangan moral. Pendidikan pertama untuk anak usia dini adalah dari orang tua, anak usia dini hanya dari observasi/mengamati dari perilaku lingkungan disekitarnya, mendengar dan menirukan. Pola asuh orang tua sangat berpengaruh pada perkembangan empati anak usia dini. Ketika berinteraksi dengan orang tua semua perilaku atau percakapan orang tua, sering dilihat maupun didengar anak maka anak akan menirukan apa yang mereka lihat dan mereka dengar.

Seseorang kehilangan empati maka perilakunya tidak terkontrol dan mengalami kondisi yang aneh hal ini dinyatakan oleh Dweck (2006 : 125). Empati bagian dari perkembangan sosial anak usia dini, empati akan berkembang dengan baik apabila siswa ada interaksi dengan orang lain. Pada saat interaksi sosial ada unsur empati sangat diperlukan, supaya tidak terjadi salah paham saat berinteraksi dengan orang lain pada saat bermain.

Bermain merupakan cara anak dalam berinteraksi soaial dengan teman sebaya untuk mengungkapkan hasil pemikirannya, perasaan. Tetapi bermain anak sekarang lebih suka bermain mengunakan handphone atau gadget daripada bermain dengan teman sebaya, sehingga anak tidak peduli dengan sekitarnya. Maka empati perlu dibiasakan sejak usia dini dimana anak usia dini pada tahap pendidikan awal. Supaya anak usia dini dalam tahap perkembangan sosial tidak mengalami masalah.

Empati merupakan salah satu indikator dari perilaku prososial telah di uji selama masa kanak-kanak menunjukan konsistensi sampai remaja dan usia dewasa Eisenbreg, Gutherie, Cumberland, Murphy, Shepard, Zhou, Gustavo, (2002 : 131-164). Walaupun anak usia dini masih terbatas keterampilan nalar, berintaksi dengan orang lain namun bisa menunjukan. Misalkan anak usia 
dini memeluk temannya sedang menangis, tanpa adanya komunikasi maupun berfikir.

Empati sangat dibutuhkan anak usia dini supaya perkembangan sosial tidak mengalami hambatan. Dari hasil observasi di TK Aisyiyah $\mathrm{X}$ ada anak empatinya kurang seperti halnya:

1. Pada saat bermain ada teman yang menangis, justru anak membiarkan saja tanpa mendekati maupun menghibur temannya yang menangis.

2. Ada teman yang sakit tidak menjenguk.

3. Tertawa saat melihat temannya jatuh.

4. Dalam permainan kooperatif saat petak umpet hanya satu anak yang selalu untuk mencari.

Untuk mengatasi masalah perkembangan sosial terutama empati anak, seperti yang dikemukakan Santrock (2007 : 126) bisa dilakukan dengan menumbuhkan empati pada anak, karena empatisangat berkontriburi pada perkembangan anak.

Oleh karena itu empati harus dimiliki anak usia dini. akan tetapi empati ini belum sepenuhnya dimiliki oleh anak TK. Sehingga perlu ditingkatkan empati melalui kepekaan perasaan dengan melihat media audio visual.

\section{METODE PENELITIAN}

Metode penelitian ini mengunakan metode eksperimen (Creswell 2010 : 235-248), untuk mengetahui efektifitas layanan informasi bimbingan konseling berbantuan media audio viual untuk meningkatakan perilaku prososial siswa TK.

Rancangan metode eksperimen pada penelitian ini mengunakan kuasi eksperimen. Kelompok eksperimen diberi perlakuan khusus yaitu layanan informasi bimbingan konseling berbantuan media audio visual dengan materi- materi empati, sedangkan kelompok kontrol tidak diberikan materi-materi empati, hal ini bertujuan untuk mengetahui apakah terdapat perbedaan antara dua kelompok yang diberikan perlakuan dengan materi-materi empati dengan yang tidak diberikan materi-materi dalam peningkatan empati siswa. Selanjutnya menganalisis tingkat empati siswa sebelum dan sesudah mengikuti layanan informasi bimbingan konseling berbantuan media audio visual menggunakan desain kelompok pretes - postes. 
Tabel 1

Deskripsi Uji Layanan Informasi Bimbingan Konseling Berbantuan Media Audiovisual Terhadap Siswa pada Kelompok Eksperimen dan Kontrol

\begin{tabular}{|c|c|c|c|}
\hline Kelompok & Pretes & Perlakuan & Postest \\
\hline Eksperimen & 0 & $\mathrm{X}$ & 0 \\
\hline Kontrol & 0 & - & 0 \\
\hline
\end{tabular}

Analisis efektifitas layanan informasi bimbingan konseling berbantuan media audio visual terhadap emapti siswa. Langkah penelitian dengan menganalisis tingkat empati siswa sebelum dan sesudah mengikuti layanan informasi berbantuan media audio visual dalam pengujian di Kelompok kontrol dan eksperimen adalah siswa TK.

Sumber data penelitian ini adalah siswa TK kelompok A1 dan A2 di Taman Kanak- Kanank Aisyiyah X Jaten, Karanganyar, jumlah siswa kelas A1 24 dan jumlah siswa kelas A2 24, serta 4 guru sebagai informan.

Teknik pengumpulan data pada penelitian ini mengunakan pedoman observasi dan wawancara. Pedoman observasi yang dikembangan adalah tentang empati siswa TK Aisyiyah. Konstruk tersebut didasarkan pada teori empati Richard Gross (2013: 165-166) menulis buku dengan judul Psychology: The Science of mind and bahaviour. Dalam buku tersebut Richard Gross menyaring pengertian empati dalam perilaku prososial yang dikemukakan Schroeder. Dengan menyusun pedoman observasi yang tersetruktur akan mempermudah pelaksanaan observasi, oleh karena itu perlu menyusun kisi- kisi observasi yaitu

1) Penyusunan Kisi - kisi observasi

Kisi- kisi pedoman observasi mengungkap empati siswa TK Aisyiyah X Jaten, Karanganyar (guided observation), observasi yang terencana, diarahkan sesuai dengan tujuan (Sutoyo,A. 2009: 79). adapun kisi-kisi dan pedoman observasi sebagai alat mengungkap ketersediaan kondisi fasilitas bimbingan dan konseling disekolah.

Tekhnik ini dipergunakan untuk memperkuat data tentang perencanaan, penyusunan, pelaksanaan dan evaluasi program layanan informasi berbantuan media audio visual yang dilakukan terhadap guru pembimbing di lokasi penelitian.

2) Pedoman wawancara untuk mengungkap data tentang pelaksanaan bimbingan dan konseling disekolah. Wawancara ini dilakukan untuk mengetahui 
program layanan informasi yang diterapkan pada lokasi penelitian mencakup perencanaan layanan, penyusunan layanan, pelaksanaan layanan, evaluasi layanan, hambatan- hambatan yang ditemukan dalam pelaksanaan layanan, dan solusi yang telah diupayakan oleh guru pembimbing. Bentuk pernyataan dalam wawancara yaitu pernyataan yang berstuktur, dimana responden dituntut untuk menjawab sesuai dengan kisi-kisi wawancara.

3) Analisis data penelitian sebagai berikut pada penelitian uji normalitas pada kelompok kontrol dan kelompok eksperiment. Berdasarkan hasil uji normalitas di atas diketahui bahwa nilai signifikansi (symp.sig. (2-tailed)) masingmasing bernilai >0,05. Hal ini berarti sebaran data penelitian normal. Langkah kedua uji linieritas dan homogenitas, uji ttest hasil dari pre-test dan postest.

\section{HASIL DAN PEMBAHASAN}

Hasil t-test untuk kelompok eksperimen (pair 1) diketahui nilai $\mathrm{t}$ hitung - 35.216, menunjukkan bahwa sebelum dilakukan layanan informasi berbantuan media audio visual lebih kecil dari setelah layanan informasi berbantuan media audio visual, dengan signifikansi sebesar $0,000<0,05$ maka Ho ditolak, artinya ada beda rerata antara nilai pretest dan postest. Dimana nilai negatif (-) menunjukkan bahwa empati siswa TK sebelum diberi layanan informasi berbantuan media audio visual lebih rendah dari empati siswa TK sesudah diberi layanan informasi berbantuan media audio visual. Hal ini dapat diartikan bahwa layanan informasi berbantuan media audio visual efektif terhadap empati siswa

Hasil t-test untuk kelompok kontrol (pair 2) diketahui nilai $\mathrm{t}$ hitung -0.182, dengan signifikansi sebear 0,857>0,05 maka Ho diterima, artinya tidak ada beda rerata antara nilai pretest dan postest pada kelompok kontrol. Jadi dapat diartikan bahwa pada kelompok kontrol antara nilai pretest dengan nilai postest tidak ada bedanya.

Hasil t-test untuk pretest kelompok ekperimen dengan kelompok kontrol diketahui nilai $\mathrm{t}$ hitung -1.713, dengan signifikansi sebear 0,101>0,05 maka Ho diterima, artinya tidak ada beda rerata antara nilai pretest kelompok eksperimen dengan nilai pretest kelompok kontrol. Jadi dapat diartikan bahwa tidak ada bedanya nilai pretest pada kelompok eksperimen dengan kelompok kontrol.

Hasil t-test untuk postest kelompok ekperimen dengan 
kelompok control diketahui nilai $\mathrm{t}$ hitung 14.743, menunjukkan bahwa nilai postetst pada kelompok eksperimen lebih besar dibandingkan nilai postest pada kelompok kontrol, dengan signifikansi sebesar $0,000<$ 0,05 maka Ho ditolak, artinya ada beda rerata antara nilai postest kelompok eksperimen dengan kelompok kontrol. Dimana nilai positif (+) menunjukkan bahwa prososial siswa TK kelompok eksperimen dengan diberi layanan informasi berbantuan media audio visual lebih tinggi daripada prososial siswa TK kelompok kontrol yang tidak diberi model layanan informasi berbantuan media audio visual. Hal ini dapat diartikan bahwa model layanan informasi berbantuan media audio visual effektif terhadap empati siswa.

Berdasarkan kondisi awal empati anak TK Aisyiyah X Jaten Karanganyar sebagaimana dalam survey awal menunjukkan adanya berbagai macam fenomena antara lain: Kurang peduli terhadap orang lain. Pada umumnya anak TK tidak peduli dengan keadaan kelas yang kotor, tidak peduli dengan teman yang belum mendapatkan tempat duduk. Masih kurangnya perilaku tolong menolong dikalangan anak TK. Menurut beberapa ahli bahwa pengembangan empati anak usia dini dapat peneliti simpulkan empati merupakan kemampuan anak dalam memahami perasaan orang lain Golmen 1997. Dalam permen RI nomor 58 (2009) mengatakan sikap dan prilaku baik dan menunjukan empati pada anak, yang ditujukan dengan mau bermain dengan teman, menolong, berbagi. perilaku anak TK yang tidak mau meminjamkan alat tulis kepada temannya. Hasil penelitian layanan informasi berbantuan media audio visual terhadap 82 siswa TK Aisyiyah $\mathrm{X}$ Jaten Karanganyar menunjukkan.

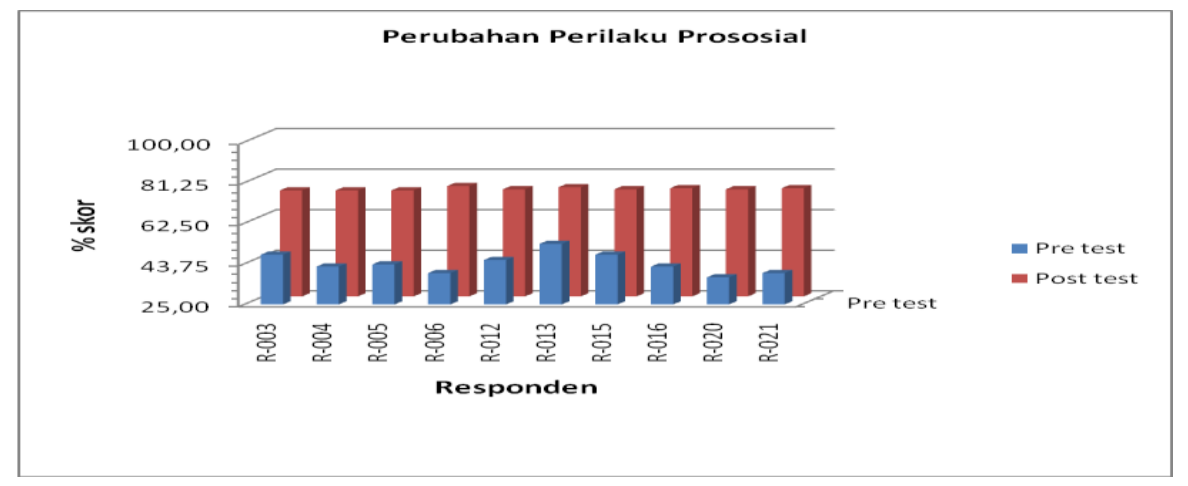

Grafik 4.1. Data Deskriptif Pretest Perubahan empati siswa sebelum layanan dan sesudah layanan dalam bentuk diagram batang

Dari analisis secara individual, siswa yang menunjukan peningkatkan empati sangat tinggi berdasarkan skor yang ditunjukan 
pada tabel 3.1 adalah R-006 dan R020 adalah siswa laki - laki. Dari pengamatan penulis, kedua siswa tersebut selama kegiatan layanan informasi berbantuan media audio visual termasuk siswa yang paling antusias dan aktif dalam menyampaikan pesan dari media audio visual.

\section{SIMPULAN}

Berdasarkan hasil penelitian menunjukan bahwa pelaksanaan layanan informasi berbantuan media audio visual masih belum maksimal. Hasil t-test untuk postest kelompok ekperimen dengan kelompok kontrol diketahui nilai $\mathrm{t}$ hitung 14.743, menunjukkan bahwa nilai posttest pada kelompok eksperimen lebih besar dibandingkan nilai postest pada kelompok kontrol, dengan signifikansi sebesar $0,000<0,05$ maka Ho ditolak, artinya ada beda rerata antara nilai postest kelompok eksperimen dengan kelompok kontrol. Dimana nilai positif (+) menunjukkan bahwa prososial siswa TK kelompok eksperimen dengan diberi model layanan informasi dengan berbantuan media audio visual lebih tinggi daripada prososial siswa TK kelompok kontrol yang tidak diberi model layanan informasi dengan berbantuan media audio visual.

Dari hasil keefektifan hasil pre test dan post test dengan adanya layanan informasi dengan berbantuan media audio visual terhadap empati siswa TK Aisyiyah X Karanganyar.

Keefektifan Model Lay anan Informasi berbantuan media audio visual terhadap empati siswa

Siswa TK $=\frac{\text { Rata }- \text { rata nilai Post test }- \text { Rata }- \text { rata nilai Pre test }}{\text { Rata }- \text { rata nilai Pre test }} \times 100 \%$

Keefektifan Lay anan Informasi dengan Bantuan Media Audio Visual terhadap empati

$$
\begin{aligned}
\text { Siswa TK } & =\frac{147,21-87,67}{87,67} \times 100 \% \\
& =0,6792 \times 100 \% \\
& =67,92 \%
\end{aligned}
$$

Hal ini dapat diartikan bahwa model layanan informasi dengan berbantuan media audio visual efektif untuk meningkatkan prososial siswa di TK. Keefektifan Hasil pre test dan post test dengan adanya model layanan informasi dengan berbantuan media audio visual, 
keefektifan model layanan informasi dengan berantuan media audio visual terhadap prososial siswa TK sebesar $67,92 \%$.

\section{DAFTAR PUSTAKA}

Adhiputra, Anak Agung.(2013) Bimbingan dan Konseling Aplikasi di Sekolah dasar dan Taman Kanak-kanak. Yogjakarta: Graha Ilmu.

Creswell, John W, (2010) Research Design, edisi ketiga. (Penerjemah Achmad Fawaid) Yogjakarta : Pustaka pelajar.

Fidrayani, (2015) Seminar Psikologi \& Kemanusiaan Pengembangan Empati Pada Anak Sekolah Dasar, ISBN:978-979-796-324B, Psycology Forum UMM

Dweck, C (2006) mindset : the new psycology of success. random house.

Eisenberg, N, (2002). Empathyrelated emotional responses, altruism and their socialization. In R,J Davidson \& A Harrington (Eds), Vision of Concern for others western scientists and tibetan budhists exanine human nature (pp.131-164) London, Oxford University Press.
Eisenberg, N., Guthrie, I. K., Cumberland, A., Murphy, B. C., Shepard, S. A., Zhou, Q., \& Carlo, G. (2002). Prosocial development in early adulthood: A longitudinal study. Journal of Personality and Social Psychology, 82(6), 993-1006.

Depdiknas, Direktorat Jendral Manajemen Pendidikan Dasar dan Menengah, Direktorat Pembinaan Taman Kanakkanak dan Sekolah Dasar. (2006). Panduan Bimbingan di TK.

Groos, R. (2013). Psychology The Science of Mind and Behaviour. Cetakan 1. (alih bahasa : Drs Helly Prajitno Soetjipto, M. A dan Dra Sri Mulyantini Soetjipto). Yogyakarta : Pustaka Pelajar.

Hoffman, M. L. (2001). Empathy and Moral Development: Implications for Caring and Justice. Review Zora RabotegŠarić Contemporary Sociology (Vol. 30). 487-488

Santrock, J.W. (2012). Perkembangan Masa Hidup (Life Span Devolepment) Jilid 1.(alih bahasa : Benedictine Widyasinta). Jakarta: Erlanga.

Sutoyo, A. (2009). Pemahaman Individu. Semarang : CV .Widya Karya. 